\title{
PENGARUH PROSES DAN KONSENTRASI ASAP CAIR CANGKANG KELAPA SAWIT TERHADAP SIFAT FISIK DAN CEMARAN MIKROBA RUBBER SHEET
}

\section{THE EFFECT OF PROCESS AND CONCENTRATION OF LIQUID SMOKE PALM SHELL TO PHYSICAL PROPERTIES AND MICROBIAL CONTAMINATION OF RUBBER SHEET}

Ageng Priatni, Fauziati, Yuni Adiningsih

Balai Riset dan Standardisasi Industri Samarinda

Jl. MT. Haryono/Banggeris No. 1 Samarinda

Alamat Email : agengpriatni@yahoo.co.id

\author{
Diterima : 02-05-2018
}

Direvisi : 08-11-2018

Disetujui : 15-11-2018

\begin{abstract}
ABSTRAK
Asap cair adalah salah satu asam anorganik yang dapat digunakan sebagai penggumpal lateks dimana asap cair memiliki pH 2,8-3,2. Asap cair dapat diperoleh melalui pembakaran cangkang kelapa sawit yang banyak mengandung hemiselulosa, selulosa serta lignin melalui proses pirolisis. Penelitian ini bertujuan untuk mengetahui pengaruh proses dan konsentrasi asap cair cangkang kelapa sawit terhadap sifat fisik dan cemaran mikroba dari lembaran karet dengan cara menggumpalkan lateks segar dengan asap cair konsentrasi $2 \%, 6 \%, 10 \%, 14 \%$ dan larutan asam formiat $2 \%$ sebagai kontrol serta perendaman. Lembaran karet yang dihasilkan kemudian dianalisa kadar airnya, nilai Po dan PRI serta cemaran mikroba (kapang dan Khamir). Penggumpal yang terbaik kemudian diaplikasikan pada pembuatan RSS dan diuji berdasarkan SNI 1903-2011. Dari penelitian ini diperoleh hasil bahwa penggumpal terbaik adalah asap cair cangkang kelapa sawit konsentrasi $14 \%$ dan tanpa perendaman dimana diperoleh lembaran karet dengan kadar air 1,52 \%, nilai Po 47, nilai PRI 86 serta jumlah kapang 23 koloni/g dan khamir 7 koloni/g. RSS yang diperoleh dari asap cair $14 \%$ bisa digunakan sebagai bahan baku SIR 20.
\end{abstract}

Kata Kunci: Asap Cair, Cangkang Kelapa Sawit, Penggumpal Lateks, RSS

\begin{abstract}
Liquid smoke is one of the inorganic acids that can be used as a latex coagulation where liquid smoke has a pH of 2,8-3,2. Liquid smoke can be obtained by burning palm shells containing hemicellulose, cellulose, and lignin. This study aims to knowing the effect of process and concentration of liquid smoke palm shell to physical properties and microbial contamination of rubber sheets by coagulating fresh latex with 2\%,6\%, 10\%, 14\%, and 2\% formic acid solution as control and immersion. The resulting rubber sheet is then analyzed its water content, Po and PRI values and microbial contaminants (mold and yeast). The best clot is then applied to the manufacture of RSS and tested according to SNI 1903-2011. From this research, it is found that the best agglomeration is palm oil shell smoke $14 \%$ concentration and without immersion where obtained rubber sheet with water content 1,52\%, Po 47, PRI 86 and total colony / $g$ and yeast colony $7 / g$. Rubber Smoked Sheet obtained from liquid smoke 14\% can be used as raw material SIR 20.
\end{abstract}

Keywords: Latex Coagulant, Liquid smoke, Palm Shells, Rubber Smoked Sheet 


\section{PENDAHULUAN}

D eningkatan produksi kelapa sawit akan menyebabkan peningkatan volume limbahnya, baik berupa limbah padat maupun limbah cair. Menurut Fauzi (2004), limbah kelapa sawit adalah sisa-sisa hasil tanaman kelapa sawit yang tidak termasuk dalam produk utama atau merupakan hasil ikutan dari proses pengolahan kelapa sawit. Limbah padat kelapa sawit dapat berupa tandan kosong, cangkang, janjang, dan fiber (sabut). Umumnya limbah padat industri kelapa sawit mengandung bahan organik tinggi sehingga berpotensi mencemari lingkungan.

Sebuah pabrik kelapa sawit dengan kapasitas 100 ribu ton tandan buah segar per tahun akan menghasilkan sekitar 6 ribu ton cangkang, 12 ribu ton serabut dan 23 ribu ton tandan buah kosong (Marpaung, 2009). Limbah padat kelapa sawit mengandung hemiselulosa 33,52\%, selulosa 38,52\%, lignin 20,36\%, zat ekstraktif 3,68\% dan abu sebesar $3,92 \%$. Berdasarkan komponen kimia tersebut, penumpukan dan pembakaran bukan merupakan metode yang tepat dan efektif untuk menangani permasalahan limbah padat kelapa sawit. Penanganan limbah tersebut secara tidak tepat akan mencemari lingkungan (Khor dkk, (2009). Menurut Mulia A (2007), penanganan limbah sawit baru sebatas dibakar (serat dan cangkang) dan dihamparkan pada lahan kosong sebagai mulsa/pupuk (TKS). Salah satu cara penanganan limbah padat kelapa sawit adalah dengan mengolah cangkang sawit menjadi asap cair dengan teknik pirolisis (Haryanti dkk ,2014).

Pirolisis didefinisikan sebagai proses pemanasan yang mendegradasi biomassa menjadi arang, tar dan gas. Dengan teknik pirolisis, limbah cangkang kelapa sawit dapat diolah secara cepat menghasilkan produk berupa arang dan asap. Asap yang dikeluarkan dapat dicairkan menjadi destilat (asap cair) dengan menggunakan kondensor sehingga tidak menimbulkan pencemaran lingkungan (Demirbas, 2005). Bridgwater (2004) menyatakan bahwa pirolisis merupakan dekomposisi oleh panas tanpa menggunakan oksigen. Proses ini diawali oleh pembakaran dan gasifikasi, yang diikuti oksidasi total atau parsial dari produk utama.

Asap cair adalah salah satu asam anorganik yang dapat digunakan sebagai penggumpal lateks dimana asap cair memiliki $\mathrm{pH}$ 2,8-3,2 yang tidak berbeda jauh dari $\mathrm{pH}$ asam formiat $(2,6)$ yang biasa digunakan sebagai penggumpal (Priatni dkk, 2017).

Bahan penggumpal yang umunya digunakan oleh perkebunan besar adalah asam semut atau asam cuka $2 \%$. Sebagian besar petani menggunakan koagulan atau penggumpal non anjuran seperti cuka para (66\%), TSP (8\%), Tawas (10\%) dan bahan penggumpal lainnya $1 \%$ (Syarif et. al, 2013).

Pengaruh buruk bahan penggumpal yang tidak dianjurkan tersebut adalah meningkatkan kadar kotoran dan kadar abu (Miyake, 2000), menurunkan nilai plastisitas karet dan penyusutan bobot (Purbaya dkk, 2011) serta meningkatkan biaya transportasi dan biaya pengolahan di pabrik, berakibat harga bokar yang diterima petani rendah dan citra mutu karet yang dihasilkan buruk (Suwardin \& Purbaya, 2015). Secara umum kondisi bokar dinilai masih rendah diindikasikan dengan : 1) Kadar Karet Kering (KKK) kurang dari 45\%; 2) Bokar masih banyak mengandung kontaminan; dan 3) Koagulan yang digunakan bervariasi dan berupa bahan yang tidak direkomendasikan (Suwardin \& Purbaya, 2015).

Selama ini penggunaan asam semut dinilai memberatkan para petani karena harganya yang cukup tinggi, terlebih harus bersaing dengan para perkebunan besar (Solichin, 2007). Oleh sebab itu diperlukan suatu alternatif bahan koagulan yang memiliki kualitas bekuan yang sama dengan asam semut serta terjangkau oleh para petani karet. Menurut Mutawali, D.I. (2015), selain sebagai pengawet dan pemberi aroma pada pangan, asap cair juga dapat digunakan sebagai koagulan lateks dengan sifat fungsional asap cair seperti antijamur, antibakteri, dan antioksidan dan dapat memperbaiki kualitas produk karet yang dihasilkan.

\section{Ageng Priatni, Fauziati, Yuni Adiningsih}


Beberapa penelitian terkait pemanfaatan asap cair sebagai penggumpal lateks telah dilakukan, menurut Kasim dkk (2015), asap cair dari tempurung kelapa dengan konsentrasi 1 $\%$ dan $2 \%$ dapat menggumpalkan lateks, menghambat pertumbuhan jamur pada lembar sit serta mencegah timbulnya bau. Sementara asap cair dari serbuk kayu karet (10\%) dan kayu galam (0\%) dapat meningkatkan mutu kadar karet kering menjadi 99,79\%, ketebalan terendah 2,03 $\mathrm{mm}$ dan Angka Lempeng Total 2,92 log CFU/ml serta mampu menghambat pertumbuhan bakteri dengan zona hambat $20 \mathrm{~mm}$ untuk serbuk kayu karet (10 \%) dan kayu galam (15\%) (Yulita, 2012).

Selain beberapa produk asap cair yang telah disebutkan di atas, asap cair juga dapat diperoleh dari limbah padat kelapa sawit seperti TKKS dan cangkang kelapa sawit. Menurut Fauziati dkk (2011), asap cair dapat dihasilkan dari pembakaran cangkang kelapa sawit dengan rendemen sebesar 9,03 \% dan memiliki sifat $\mathrm{pH} \mathrm{3,8}$, kandungan senyawa akif dominan yaitu Metanol, Fenol dan Furan. Ginayati dkk (2015) telah memanfaatkan asap cair dari cangkang kelapa sawit sebagai pengawet tahu dan dapat bertahan selama 56 jam, sementara menurut Khaldun \& Haji (2010) asap cair cangkang kelapa sawit dapat berpotensi sebagai biopestisida dengan nilai $\mathrm{EI}_{50}$ sebesar 67,39. Fauziati dkk (2011) juga telah mengembangkan asap cair dari cangkang kelapa sawit sebagai antiseptik pembersih tangan dan memberikan daya hambat yang kuat terhadap pertumbuhan bakteri Staphilococus aureus, E. Colli dan Salmonella. Pentingnya substitusi asam formiat sebagai penggumpal lateks serta pengolahan limbah kelapa sawit yang potensinya cukup besar menjadi latar belakang dilakukannya penelitian ini. Penelitian ini bertujuan mengetahui pengaruh proses dan konsentrasi asap cair cangkang kelapa sawit terhadap sifat fisik dan cemaran mikroba pada lembaran karet.

\section{METODE PENELITIAN \\ Bahan dan Alat Penelitian}

Bahan yang digunakan pada penelitian ini adalah Lateks segar yang diperoleh dari CV. Eja Nurcery di Marang Kayu-Kukar, Asap Cair Cangkang Kelapa Sawit, Asam Formiat Pro Analysis yang diperoleh dari Merck dan Aquadest. Sementara peralatan yang digunakan yaitu oven, sheeter, gilingan besi, timbangan, loyang, pengaduk, glass ware dan alat bantu lainnya.

\section{Metodologi}

Kegiatan penelitian dibagi menjadi beberapa tahapan yaitu:

\section{Penggumpalan lateks}

Lateks segar masing-masing sebanyak $100 \mathrm{ml}$ diencerkan dengan $100 \mathrm{ml}$ aquadest yang kemudian dimasukkan ke dalam wadah atau loyang yang berukuran $14 \times 7 \times 3 \mathrm{~cm}$, selanjutnya digumpalkan dengan $15 \mathrm{ml}$ asap cair cangkang sawit dengan konsentrasi $2 \%, 6$ $\%, 10 \%, 14 \%$ (di atas $14 \%$ maka penggumpalan berlangsung terlalu cepat sehingga tidak dapat diaduk dan tidak merata) serta larutan asam formiat $2 \%$ (AF2) sebagai kontrol. Penambahan asap cair ke dalam campuran lateks segar dan aquadest dilakukan secara perlahan sambil diaduk hingga terbentuk koagulum yang sempurna, ditandai dengan jernihnya warna serum. Kemudian gumpalan karet basah digiling menggunakan gilingan tangan diatas alas yang bersih sehingga diperoleh lembaran karet dengan ketebalan sekitar 2-3 mm. Lembaran karet selanjutnya dibilas dengan air. Lembaran yang diperoleh kemudian diperlakukan dengan 2 perlakuan : 1). Direndam dengan asap cair cangkang sawit masingmasing sebanyak $100 \mathrm{ml}$ selama 1 jam dan kemudian dikeringkan pada suhu $50{ }^{\circ} \mathrm{C}$ selama 2 jam serta 2). Tidak direndam dan langsung dikeringkan pada suhu $50{ }^{\circ} \mathrm{C}$ selama 2 jam. 
Lembaran karet kering yang dihasilkan dari tiap-tiap perlakuan kemudian dihitung kadar air dan diuji nilai Po, PRI nya serta cemaran mikroba (kapang dan kamir). Semua perlakuan di atas diulang sebanyak 3 kali.

\section{Pembuatan Rubber Smoked Sheet (RSS)}

Lateks segar yang akan diolah menjadi RSS memiliki \% Kadar Kering Karet (KKK) sebesar $34 \%$, maka dari tabel Thio Goan Loa diperoleh bahwa untuk mengolah dengan bak penggumpal bervolume 9,36 liter diperlukan lateks segar sebanyak 4,41 liter. Lateks kemudian dimasukkan ke dalam bak penggumpal dan selanjutnya ditambahkan air sebanyak 4,96 liter sambil diaduk hingga rata. Kemudian ditambahkan $300 \mathrm{ml}$ asap cair $2 \%$ sebagai penggumpal ke dalam bak sambil diaduk merata dan didiamkan hingga menggumpal dengan sempurna. Setelah menggumpal, koagulum di keluarkan dari bak dan digiling dengan gilingan besi menggunakan tangan untuk mengeluarkan air. Selanjutnya koogulum digiling dengan sheeter (4 gilingan polos) sambil disiram air hingga terbentuk lembaran sit dengan ketebalan 3-4 mm. Lembaran sit kemudian dicuci lagi dan ditiriskan dengan cara digantung kurang lebih selama 2 jam. Lembaran sit kemudian dikeringkan di kamar asap selama 5 hari dengan mengatur suhu pengeringan $40-60{ }^{\circ} \mathrm{C}$. Selanjutnya dilakukan pengujian terhadap RSS dengan parameter uji : Po, Pa, PRI, Kadar kotoran, Kadar abu, Kadar zat menguap, Nitrogen dan Viscositas money (SNI 06-1903-2000).

\section{HASIL DAN PEMBAHASAN}

\section{Kadar Air}

Kadar air adalah persentase kandungan air suatu bahan. Kadar air lembaran karet hasil penelitian tersaji pada Gambar 1.

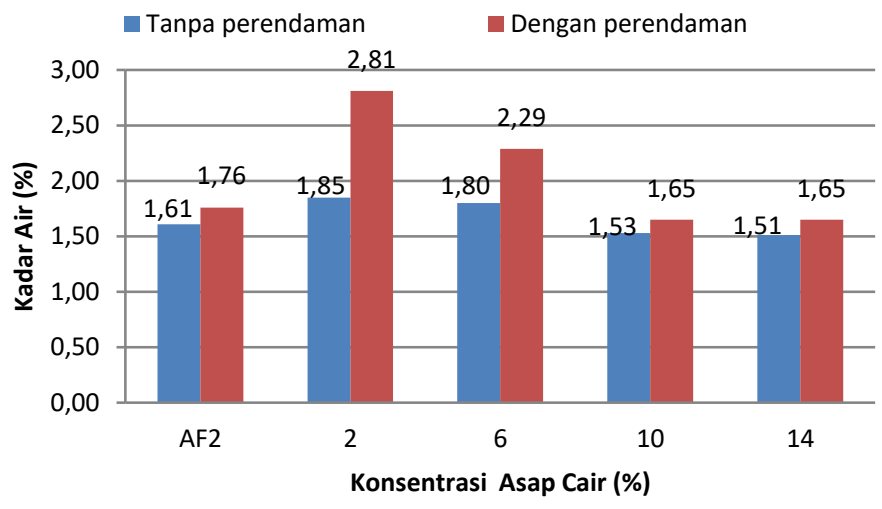

Gambar 1. Kadar Air Lembaran Karet (\%) Terhadap Konsentrasi Asap Cair

Pada Gambar 1 diketahui bahwa kadar air lembaran karet dengan penggumpal asap cair $14 \%$ baik dengan perendaman maupun tanpa perendaman memiliki nilai terkecil 1,51 $\%$ dan $1,65 \%$ dan lembaran karet dengan penggumpal asap cair $2 \%$ memiliki nilai terbesar $1,85 \%$ dan $2,81 \%$. Hal ini menunjukkan bahwa semakin kecil konsentrasi asap cair maka kadar air lembaran karet semakin besar, yang berarti konsentrasi berpengaruh terhadap kadar air. Hal ini disebabkan karena semakin kecil konsentrasi asap cair maka semakin banyak air yang digunakan sebagai pengencer dalam pembuatan asap cair tersebut dan pada akhirnya berpengaruh terhadap kadar air lembaran karet. Sementara kadar air dari lembaran karet dengan penggumpal asam formiat memiliki kadar air yang hampir sama dengan lembaran karet yang digumpalkan dengan asap cair $10 \%$ dan $14 \%$ yaitu $1,61 \%$ dan $1,76 \%$.

\section{Ageng Priatni, Fauziati, Yuni Adiningsih}

Pengaruh Proses dan Konsentrasi Asap Cair Cangkang Kelapa Sawit terhadap Sifat Fisik dan Cemaran Mikroba Rubber Sheet 
Kecenderungan juga menunjukkan bahwa kadar air lembaran karet dengan proses perendaman baik dengan penggumpal Asam Formiat maupun asap cair $2 \%, 6 \%, 10 \%$ dan $14 \%$ memiliki nilai yang lebih besar dari pada kadar air lembaran karet tanpa perendaman. Ini berarti proses perendaman berpengaruh terhadap kadar air. Besarnya kadar air diduga dikarenakan perlakuan perendaman dengan asap cair membuat air yang ada pada penggumpal masuk ke dalam lembaran karet dan berpengaruh terhadap kadar air.

Karet alam adalah polimer dari isopropene dengan rumus monomer $\left(\mathrm{C}_{5} \mathrm{H}_{8}\right)_{n}$. Adanya ikatan rangkap $-\mathrm{C}=\mathrm{C}$ - pada molekul karet, memungkinkan dapat terjadinya reaksi misalnya oksidasi (Harahap, 2009). Banyaknya senyawa-senyawa aktif serta kandungan air yang hampir 90 \% dari asap cair (Ginayati dkk, 2015) diduga bereaksi dengan ikatan rangkap molekul karet dan menghasilkan molekul air $\left(\mathrm{H}_{2} \mathrm{O}\right)$ yang berakibat meningkatnya kadar air pada lembaran karet.

\section{Plasticity Retention Index (PRI)}

Plasticity Retention Index atau PRI adalah suatu ukuran yang dapat digunakan sebagai indikator ketahanan karet terhadap degradasi akibat oksidasi pada suhu tinggi. Nilai PRI merupakan indikator mudah tidaknya karet menjadi lengket jika disimpan atau dipanaskan (Martosugito, 1989). Nilai PRI lembaran karet yang diperoleh dari hasil penelitian dapat dilihat pada Gambar 2.

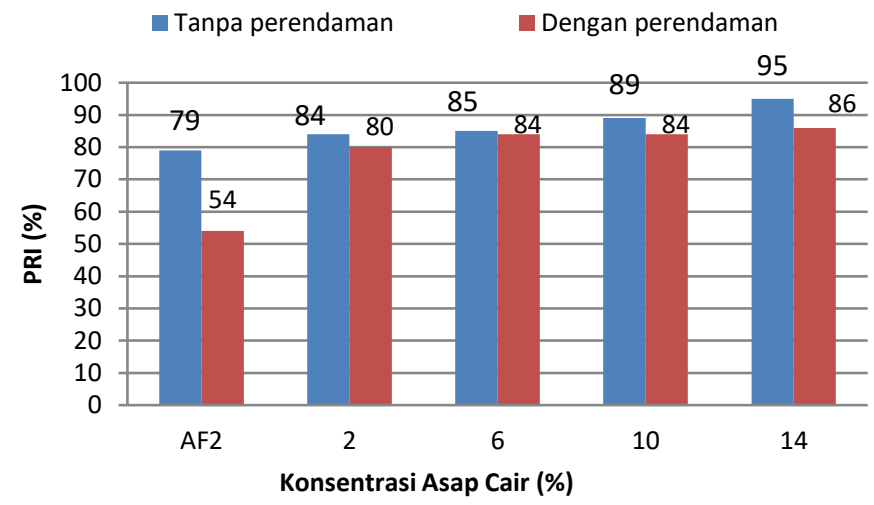

Gambar 2. Nilai PRI Lembaran Karet (\%) Terhadap Konsentrasi Asap Cair

Dari Gambar 2 menunjukkan bahwa nilai PRI terkecil diperoleh pada penggumpalan dengan asap cair konsentrasi $2 \%$ baik dengan perendaman maupun tanpa perendaman masing-masing sebesar $80 \%$ dan $84 \%$, sementara nilai PRI terbesar diperoleh pada penggumpalan dengan asap cair konsentrasi $14 \%$ yaitu $86 \%$ dan $95 \%$, baik dengan perendaman maupun tanpa perendaman.

Hasil ini menunjukkan bahwa konsentrasi asap cair berpengaruh terhadap nilai PRI. Semakin besar konsentrasi asap cair maka nilai PRI semakin besar pula yang berarti mutu lembaran karet yang dihasilkan semakin baik. Hal ini disebabkan karena semakin besar konsentrasi asap cair maka kandungan senyawa antioksidan khususnya fenol juga semakin besar sehingga semakin kecil kemungkinan lembaran karet dapat teroksidasi.

Menurut Wazyka (2000), senyawa fenol dan turunannya dapat berfungsi sebagai antioksidan yang akan melindungi molekul karet dari oksidasi pada suhu tinggi sehingga nilai PRI akan tetap tinggi. Asap cair cangkang sawit mengandung lima (5) senyawa aktif utama yaitu asam asetat $41,47 \%$, Fenol $23,68 \%$, etilen glikol $16,29 \%$, etanol $7,65 \%$ dan aceton $6,02 \%$ (Priatni dkk, 2017). 
Menurut Harahap (2009), karet yang mempunyai PRI yang tinggi berarti lebih tahan terhadap oksidasi dibandingkan karet dengan PRI yang rendah. Nilai PRI juga dapat digunakan sebagai petunjuk terhadap sifat fisik karet antara lain tegangan putus (tensile strength), kepegasan pantul (rebound resilience) dan kalor timbul (heat build up). Semakin tinggi nilai PRI maka semakin tinggi pula tegangan putus dan kepegasan pantul serta semakin rendah kalor yang timbul dari karet. Ini berarti mutu SIR yang dihasilkan semakin baik (Martosugito, 1989). Syarat uji minimum PRI = 50 untuk semua jenis SIR.

Dari Gambar 2 juga diperoleh bahwa nilai PRI untuk lembaran karet dengan penggumpal larutan Asam Formiat $2 \%$ baik dengan maupun tanpa perendaman memiliki nilai PRI paling kecil yaitu $54 \%$ dan $79 \%$. Hal ini disebabkan karena asam formiat tidak memiliki senyawa antioksida sebagaimana halnya asap cair. Asam Formiat merupakan turunan pertama asam karboksilat (Anonim, 2001), dimana gugus karboksil bukan merupakan senyawa antioksidan sebagaimana senyawa Fenol.

Gambar 2 juga menunjukkan bahwa nilai-nilai PRI dengan perendaman lebih kecil dibandingkan tanpa perendaman, yang berarti proses perendaman berpengaruh terhadap nilai PRI. Hal ini diduga, proses perendaman melarutkan senyawa-senyawa antioksida baik yang berasal dari asap cair maupun yang ada pada karet sehingga nilai PRI menjadi kecil. Menurut Harahap (2009), rendahnya nilai PRI karet yang berasal dari bahan koogulum akibat sebagian besar bahan bukan karet dari lateks terutama protein dan fosfolida yang dapat bertindak sebagai antioksida telah hilang terlarut atau terurai akibat penjemuran langsung dibawah sinar matahari, termasuk antioksida yang ada pada asap cair. Perendaman juga merupakan salah faktor yang mempengaruhi nilai PRI selain adanya ionion logam, jumlah ammonia yang ditambahkan, sinar matahari, suhu pengeringan dan penggilingan. Dalam Burfield (1986), dikatakan bahwa rendahnya nilai plastisitas dapat disebabkan karena terhalangnya ikatan silang gugus aldehida oleh adanya air.

\section{Plastisitas Awal (Po)}

Plastisitas awal atau Po adalah ukuran plastisitas karet yang secara tidak langsung memperkirakan panjangnya rantai polimer molekul ( BM ) karet. Biasanya karet dengan nilai Po menunjukkan BM nya tinggi. Syarat uji minimum Po $=30$ untuk semua jenis SIR menunjukkan bahwa karet harus memiliki BM minimum 1.300.000. SIR dengan Po kurang dari 30 biasanya disebabkan karet telah mengalami degradasi atau pemotongan rantai molekulnya, yang berakibat sifat fisik menurun. Nilai Po lembaran karet dari masing-masing perlakuan sebagaimana Gambar 3.

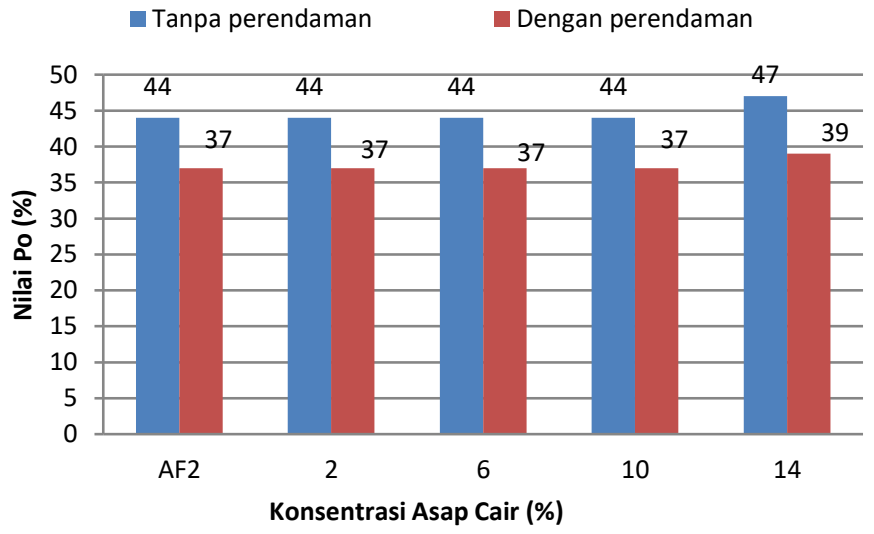

Gambar 3. Nilai Po Lembaran Karet (\%) Terhadap Konsentrasi Asap Cair

112 Ageng Priatni, Fauziati, Yuni Adiningsih

Pengaruh Proses dan Konsentrasi Asap Cair Cangkang Kelapa Sawit terhadap Sifat Fisik dan Cemaran Mikroba Rubber Sheet 
Gambar 3 menunjukkan bahwa nilai Po lembaran karet dengan penggumpal asap cair konsentrasi $2 \%, 6 \%$ dan $10 \%$ baik dengan perendaman maupun tanpa perendaman memiliki nilai Po yang sama yaitu 44 dan 37, sementara nilai Po lembaran karet dengan penggumpal asap cair konsentrasi $14 \%$ sebesar 47 dan 39 . Terjadi kenaikan nilai Po yang tidak signifikan. Ini menunjukkan bahwa konsentrasi asap cair tidak berpengaruh terhadap nilai Po.

Pada gambar 3 juga bisa dilihat bahwa nilai-nilai Po dengan perendaman lebih kecil dibandingkan tanpa perendaman, yang berarti proses perendaman berpengaruh terhadap nilai Po. Menurut Harahap (2009), karet dapat mengalami degradasi atau pemotongan rantai molekul dikarenakan beberapa faktor diantaranya penyimpanan di tempat yang tidak kering (basah), yang berakibat sifat fisik menurun diantaranya yaitu Po. Dalam hal ini, perendaman diduga mengakibatkan terjadinya degradasi sehingga terjadi penurunan nilai Po.

Gambar 3 juga menunjukkan bahwa lembaran karet dengan penggumpal larutan asam formiat $2 \%$ memiliki nilai Po yang tidak jauh berbeda dengan asap cair 2\%, $6 \%, 10 \%$ dan $14 \%$. Ini menunjukkan bahwa asap cair memiliki kemampuan sebagai koagulan/ penggumpal yang sama baiknya dengan asam formiat. Menurut Sucahyo, L (2010), asap cair dapat digunakan sebagai bahan koagulan lateks dalam proses pembuatan RSS sesuai dengan dosis standar penggunaan asam semut

\section{Cemaran Mikroba (Kapang dan Khamir)}

Pengujian cemaran mikroba berupa kapang dan khamir pada lembaran karet dilakukan untuk mengetahui pengaruh senyawa-senyawa aktif yang ada pada asap cair sebagai antimikroba dan ditunjukkan pada Gambar 4 dan 5.

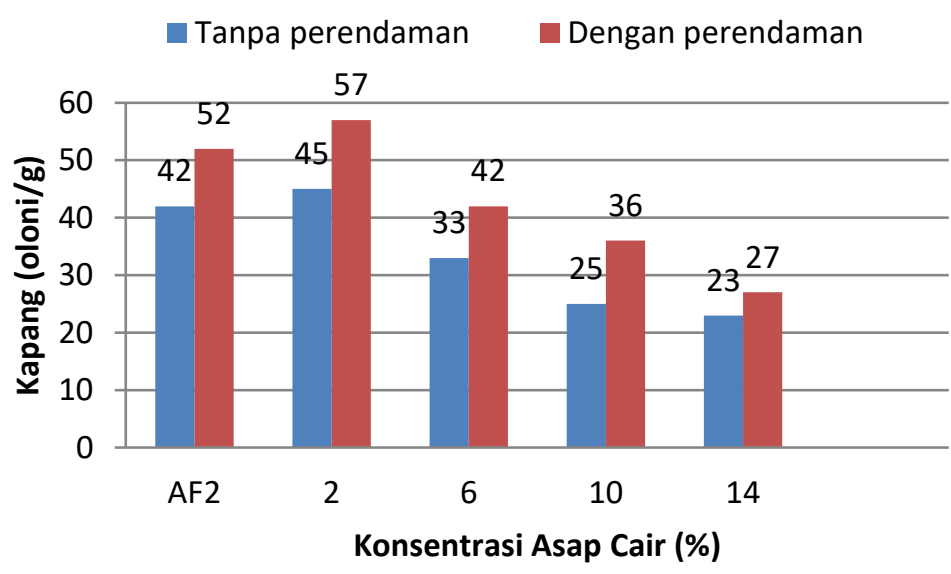

Gambar 4. Cemaran Kapang (koloni/g) Lembaran Karet Terhadap Konsentrasi Asap Cair

Gambar 4 menunjukkan bahwa cemaran kapang paling tinggi diperoleh lembaran karet dengan penggumpal asap cair konsentrasi $2 \%$ baik tanpa maupun dengan perendaman masing-masing sebesar $45 \mathrm{koloni} / \mathrm{g}$ dan $57 \mathrm{koloni} / \mathrm{g}$, sementara nilai terendah pada asap cair $14 \%$ masing-masing sebesar 23 koloni $/ g$ dan 27 koloni $/ g$. 


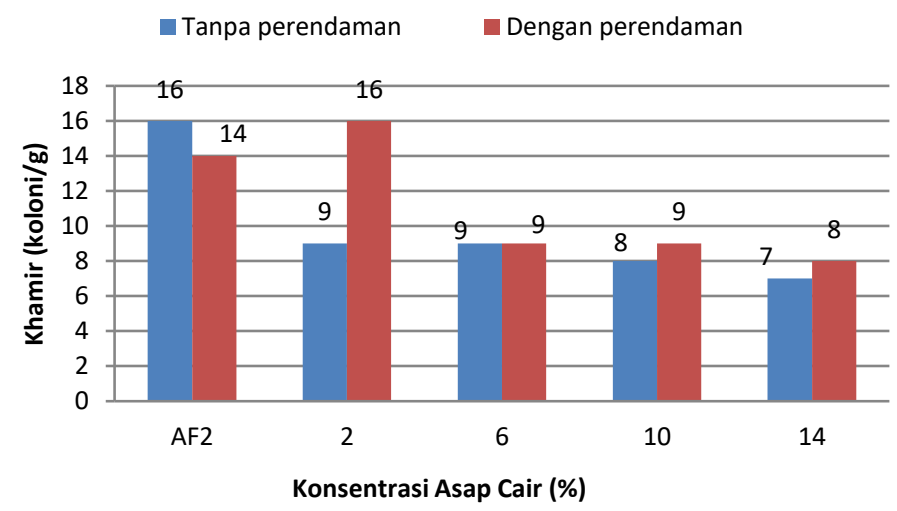

Gambar 5. Cemaran Khamir (koloni/g) Lembaran Karet Terhadap Konsentrasi Asap Cair

Gambar 5 juga menunjukkan bahwa cemaran khamir paling tinggi ada pada lembaran karet dengan penggumpal asap cair konsentrasi $2 \%$ baik tanpa maupun dengan perendaman masing-masing masing-masing sebesar 9 koloni/g dan 16 koloni/g, sementara nilai terendah pada asap cair $14 \%$ masing-masing sebesar $7 \mathrm{koloni} / \mathrm{g}$ dan $8 \mathrm{koloni} / \mathrm{g}$.

Gambar 4 dan 5 menunjukkan bahwa konsentrasi asap cair berpengaruh terhadap cemaran mikroba kapang dan khamir. Kapang adalah mikroba bersel tunggal berupa benang-benang halus berupa hifa, berkembang biak dengan spora atau membelah diri. Sedangkan khamir atau yang biasa disebut ragi adalah mikroba bersel tunggal berbentuk bulat lonjong dan memperbanyak diri dengan pembentukan tunas (BSN, 2009). Adanya kapang dan khamir dapat menyebabkan pembusukan pada lembaran karet atau sheet terutama selama distribusi atau pada saat penyimpanan di gudang. Dengan adanya peningkatan konsentrasi asap cair sebagai penggumpal akan meningkatkan kemampuan sifat antimikroba sebagaimana ditunjukkan Gambar 4 dan 5.

Asap cair memiliki senyawa-senyawa aktif yaitu asam asetat 41,47 \%, Fenol 23,68 \%, etilen glikol 16,29 \%, etanol 7,65 \% dan aceton 6,02 \% (Priatni dkk, 2017). Senyawa Fenol dan asam merupakan senyawa yang sudah banyak diketahui mempunyai sifat antimikroba. Fenol (carbolic acid) diketahui dapat bersifat antimikroba karena mampu menginaktifkan enzim-enzim essensial, mengkoagulasi SH group dan $\mathrm{NH}$ group protein dari karet (Kane dan Judy, 1996).

Asam-asam organik lemah (asam asetat, asam propionat, asam laktat, asam benzoate dan asam salisilat) dapat bersifat sebagai antimikrobia terutama karena pembentukan ion $\mathrm{H}^{+}$ bebas (Davidson dan Branen, 1993) sehingga dapat menghambat pertumbuhan mikroba pada lembaran karet. Sementara asam propionat mampu menghambat mikrobia dengan cara memblok system metabolisme sel protein karet melalui penghambatan terhadap aktivitas enzim (Luck dan Jager, 1997). Selain itu asam propionat dapat menurunkan nilai pH antar seluler yang dapat berakibat pada penghambatan atau terbunuhnya sel.

Gambar 4 dan 5 juga menunjukkan bahwa untuk perlakuan perendaman memiliki cemaran mikroba kapang dan khamir yang lebih tinggi dibandingkan tanpa perendaman. Hal ini diduga karena lembaran karet dengan perendaman memiliki kadar air lebih tinggi dibandingkan dengan tanpa perendaman sebagaimana Gambar 1 sehingga lebih mudah untuk dicemari Kapang dan Khamir. Pertumbuhan mikroba dipengaruhi oleh suhu, kadar air, kelembapan, pH dan oksigen (Reddy dan Waliyar 2008).

Sementara untuk lembaran karet dengan penggumpal larutan asam formiat $2 \%$ memiliki cemaran paling tinggi, hal ini dikarenakan asam formiat tidak memilki senyawa aktif sebagaimana asap cair. Asam Formiat merupakan turunan pertama asam karboksilat

\section{Ageng Priatni, Fauziati, Yuni Adiningsih}

Pengaruh Proses dan Konsentrasi Asap Cair Cangkang Kelapa Sawit terhadap Sifat Fisik dan Cemaran Mikroba Rubber Sheet 
(Anonim, 2001), dimana gugus karboksil bukan merupakan senyawa antioksidan sebagaimana senyawa Fenol.

\section{RSS (Rubber smoke sheet)}

Dari penggumpalan lateks diperoleh hasil bahwa lembaran karet dengan penggumpal asap cair konsentrasi $14 \%$ tanpa perendaman memiliki kadar air yang rendah, Po dan PRI yang tinggi serta memiliki cemaran mikroba (kapang dan Khamir) yang lebih sedikit dari pada asap cair $10 \%, 6 \%$ dan $2 \%$. Asap Cair $14 \%$ tanpa perendaman kemudian digunakan sebagai penggumpal untuk pembuatan RSS. Terhadap RSS yang dihasilkan kemudian dilakukan uji berdasarkan standar SIR SNI 1903-2011 dengan larutan asam formiat $2 \%$ sebagai kontrol dan diperoleh hasil sebagaimana Tabel 1.

Tabel 1. Hasil Uji Mutu Berdasarkan SNI 1903-2011

\begin{tabular}{lccc}
\hline \multirow{2}{*}{ Parameter } & \multicolumn{2}{c}{ Hasil Uji } & SNI 06-1903-2000 \\
\cline { 2 - 4 } & $\mathbf{1}$ & $\mathbf{2}$ & SIR 10 \\
\hline Kadar Kotoran (\%) & 0,11 & 0,01 & Maks 0,08 \\
\hline Kadar Abu (\%) & 0,35 & 0,32 & Maks 0,75 \\
\hline Kadar Zat Menguap (\%) & 0,64 & 0,58 & Maks 0,80 \\
\hline PRI & 85,1 & 67,1 & Min 30 \\
\hline Po & 57,0 & 42,5 & Maks 0,60 \\
\hline Nitrogen (\%) & 0,36 & 0,54 & \\
\hline Ket. : & & \\
1 = RSS dengan penggumpal larutan Asam Formiat 2 \% & \\
2 = RSS dengan penggumpal Asap Cair 14 \%
\end{tabular}

Pada Tabel 1 diperoleh hasil bahwa RSS yang dihasilkan dengan penggumpal asap cair 14 \% memenuhi baku buku SNI 06-1903-2000 untuk SIR 10. Sementara pada RSS dengan penggumpal larutan asam formiat $2 \%$, terdapat dua parameter yang tidak memenuhi baku mutu yaitu kadar kotoran $0,11 \%$ dimana maks nya $0,1 \%$ dan viskositas moneey 82 dimana batasnya yaitu 65-75.

\section{KESIMPULAN}

Dari penelitian diperoleh kesimpulan bahwa penggumpal yang baik adalah asap cair 14 $\%$ tanpa proses perendaman, menghasilkan lembaran karet dengan kadar air 1,52 \%, nilai PRI 86, jumlah kapang 23 koloni/g dan khamir 7 koloni/g. RSS yang dihasilkan memenuhi syarat mutu SNI 06-1903-2011 untuk SIR 10.

\section{UCAPAN TERIMA KASIH}

Penelitian ini didanai oleh Balai Riset dan Standardisasi Industri Samarinda. Terima kasih yang sebesar-besarnya penulis sampaikan kepada Bapak Kepala Baristand Industri Samarinda yang secara non teknis telah memberi dukungan sehingga penelitian ini berjalan lancar.

\section{DAFTAR PUSTAKA}

Anonim. 2011. Asam Formiat. Lestarieka. https://lestarieka.wordpress.com/2011/07/01/ asam-format/. Diakses tgl. 24 Oktober 2017.

Bridgwater, A.V. 2004. Biomass Fast Pyrolysis. Thermal Science 8(2):21-49. 
Burfield, D. R. 1986. Storage Hardening of Natural Rubber : an Examination of Current Mechanistic Proposals. Journal Natural Rubber 1(3) : 202-208.

BSN. 2009. Batas Maksimum Cemaran Mikroba Dalam Pangan (SNI 7388:2009). BSN. Jakarta.

BSN. 2011. SNI SIR (SNI 1903-2011). BSN. Jakarta.

Davidson, M.P and Branen, A.L. 1993. Antimicrobial in Foods. $2^{\text {nd }}$ ed. Revised and expanded. Marcel.

Demirbas, A. 2005. Pyrolisis of Ground Wood in Irregular Heating Rate Conditions. J. Anal and Applied Pyrolisis, p. 39-43.

Fauzi, Y. 2004. Kelapa Sawit. Edisi Revisi. Jakarta: Penebar Swadaya. Gani, A. 2007. Konversi Sampah Organik Menjadi Komarasca (Kompos-Arang Aktif-Asap Cair) dan Aplikasinya pada Tanaman Daun Dewa. Disertasi tidak diterbitkan. Bogor: Sekolah Pascasarjana IPB.

Fauziati, Ella E, Prasetyo I, Fitriani \& Gasi. 2011. Pengembangan Wood Vinegar dari Limbah kelapa sawit Sebagai Antiseptik Pembersih Tangan (Laporan Penelitian). Baristand Industri Samarinda. Samarinda.

Ginayati, L. Faisal, M \& Suhendrayatna. 2015. Pemanfaatan Asap Cair Dari Pirolisis Cangkang Kelapa Sawit Sebagai Pengawet Alami Tahu. Jurnal Teknik Kimia USU Vol. 4 No. 3 September 2015. USU. Medan.

Harahap, R. 2009. Analisa Perbandingan Nilai PRI dari Produk SIR 20 dan SIR 3 Untuk Temperatur Berbeda-beda-Karya IImiah. FMIPA-UNSU. Medan.

Hidayoko, G dan Okta, W. 2014. Pengaruh Penggunaan Jenis Bahan Penggumpal Lateks Terhadap Mutu SIR 20. AGRITEPA Vol. 1, No 1 Juni 2014. UNIVED. Bengkulu.

Kane, L and Judy, K. 1996. Microbial Essensials and Aplication. $2^{\text {nd }}$ edition. Mc Graw Hill inc. New York.

Kasim, F., Fitriah, A.N \& Hambali, E. 2015. Aplikasi Asap Cair pada Lateks. Jurnal PASTI Vol. IX No. 1. IPB. Bogor.

Khaldun, I \& Haji, A.G. 2010. Potensi Asap Cair Hasil Pirolisis Cangkang Kelapa Sawit Sebagai Biopestisida Antifeedant. Seminar Nasional Sains \& Teknologi-III. Lemlit Universitas Lampung. Lampung.

Khor, K.H., K.O. Lim, dan Z.A. Zainal. 2009. Characterization of Bio-Oil: A ByProduct from Slow Pyrolysis of Oil Palm Empty Fruit Bunches. Am. J. Applied Sciences 6(9):16471652

Luck, E dan M. Jager. 1993. Antimicrobial Food Aditives Characteristics Uses, Effect. $2^{\text {nd }}$ revised and Enlarged edition.

Marpaung, DS. 2009. Pemanfaatan Limbah Pabrik Kelapa Sawit Sebagai Pembangkit Listrik. http:// Dedy Suhendra Marpaung. Blok.spot.com, Oktober, 2009.

Martosugito, 1989, Pengolahan SIR, Departemen Perdagangan Indonesia, Jakarta.

Miyake, I. 2000. Recent advance in tire technology and its impact on natural rubber marketing. Proc. Indonesian Rubb. Conf. and IRRDB Symp. 2000. Bogor. Indonesian Rubber Research Institute, 23 - 33.

Mulia, A. 2007. Pemanfaatan Tandan Kosong Kelapa Sawit \& Cangkang Kelapa Sawit Sebagai Bricket Arang. Tesis-Sekolah Pasca Sarjana Universitas Sumatera Utara. Medan.

Mutawali, D.I. 2015. Impregnasi dengan Asap Cair Terhadap Kualitas Ribbed Smoked Sheet di PT. Perkebunan Nusantara III Dolok Merawan. Jurnal Pendidikan Kimia. Vol.8, No.1, April 2016, 71-79. USU. Medan.

Ompusunggu, M. 1995. Penanganan bahan baku dan proses pengolahan karet alam di Indonesia. Laporan Intern. Pusat Penelitian Karet, Medan.

116 Ageng Priatni, Fauziati, Yuni Adiningsih

Pengaruh Proses dan Konsentrasi Asap Cair Cangkang Kelapa Sawit terhadap Sifat Fisik dan Cemaran Mikroba Rubber Sheet 
Priatni, A., Fauziati, Adiningsih, Y., Sirait, J. dan Sulharman. 2017. Pemanfaatan Asap Cair Dari Cangkang Sawit Sebagai Penggumpal Lateks-Laporan Penelitian. Baristand Industri Samarinda. Samarinda.

Purbaya, M., Sari, T.I., Saputri, C.A. \& Fajriaty, M.T. 2011. Pengaruh Beberapa Jenis Bahan Penggumpal Lateks Dan Hubungannya Dengan Susut Bobot, Kadar Karet Kering Dan Plastisitas. Prosiding Seminar Nasional AVoER ke-3. Palembang.

Santi, S.R. 2010. Senyawa Aktif Antimakan dari Umbi Gadung (Dioscoka hispida Dennst). Jurnal Kimia 4(1):71-78

Sarles, Frazier, Wilson dan Knight. 1956. Microbiology. Harper and Brohtres. New York.

Solichin, M. 2007. Penggunaan Asap Cair Deorub dalam Pengolahan RSS. Jurnal Penelitian Karet, Vol.25(1) : 1-12.

Suwardin, D \& Purbaya, M. 2015. Jenis Bahan Penggumpal \& Pengaruhnya Terhadap Parameter Mutu Karet Spesifikasi Teknis. Warta Perkaretan 2015, 34 (2), 147-160.

Sucahyo, L. 2010. Kajian Pemanfaatan Asap Cair Tempurung Kelapa Sebagai Bahan Koagulan Lateks dalam Pengolahan RSS dan Pengurang Bau Busuk Bahan Olahan Karet-Skripsi. IPB. Bogor.

Wazyka, Agung. 2000. Aktivitas Antioksidan Asap Cair Kayu Karet Dan Redistilatnya Terhadap Asam Linoleat Dan Poliisopropen. Tesis Program Studi Ilmu Dan Teknologi Pangan, Jurusan Ilmu Pertanian. Program Pasca Sarjana Universitas Gadjah Mada, Yogyakarta.

Yulita, E. 2012. Pengaruh Asap Cair Serbuk Kayu Limbah Industri Terhadap Mutu Bokar. Jurnal Riset Industri Vol. VI No. 1 2012. Kementerian Perindustrian. Jakarta. 